\title{
An Error Analysis of Students' Writing in Narrative Text
}

\author{
Helmiyadi \\ STKIP Bumi Persada Lhokseumawe, Aceh \\ helmiyadi_1987@yahoo.com \\ Nurul Kamaliah \\ STKIP Bumi Persada Lhokseumawe, Aceh \\ nurul_kamaliah55@yahoo.com
}

\begin{abstract}
The aimed of the research was to find out the errors which were commonly made by the students of Sekolah Menengah Kejuruan Swasta Bustanul Yatama Syamtalira Bayu in their writing narrative text and to find out the causes of errors in their writing narrative text. This research useds a qualitative and quantitative approach. The population of this research was all the students of the Second year students of Sekolah Menengah Kejuruan Swasta Bustanul Yatama Syamtalira Bayu in academic year 2020/2021 consisted of 120 students and divided into 56 male students and 64 female students. The sample of this research selected by using random sampling technique by using lottery. In this study, only 20 students and one English teacher involved as the sample. The researcher use two kinds of instruments, they are test and interview. In analyzing the data, the writer used a percentage formula from Sudjana. Result of the research from test most of the first year students of Sekolah Menengah Kejuruan Swasta Bustanul Yatama Syamtalira Bayu made many errors in grammatical aspects in writing, a high percentage of errors was found in one out of three categories. The highest error category was tense errors. Moreover, the students felt difficult in getting ideas to begin free writing. The causes of errors were made by the students because of lack of interactive facilities is one of the problems to develop interactive classroom activities. Based on this reasoning, it can be concluded that many of the students made errors because of interlingual and intralingual transfer.
\end{abstract}

Keywords: Error Analysis, Writing, Narrative Text

Submitted: November 12, 2020

Reviewed: April 1, 2021

Published: May 3, 2021

How to Cite: Helmiyadi and Nurul Kamaliah. 2021. An Analysis of Students' Writing in Narrative Text. Vol 5 (1): pp. 51-64. DOI: https://doi.org/10.24036/jess.v5i1

\section{Introduction}

There are many kinds of text that can be used such as narrative, recount, report, explanation, descriptive, and procedure text. They are very useful of the teacher to achieve the instructional goals of teaching learning process and they can also be interesting for the students and can create English text. Although somebody can read well, it is expressed in writing and we expose our idea but to make students write well, it is so difficult to do. Many students found some difficulties while writing, especially grammar, (Nunan, 1995) states that one of the obstacles that the students face in learning English is grammar lesson because it is difficult and boring. Besides the other reasons why students have difficulties in learning 
grammar are students learn more slowly and forget things quickly, get bored easily, may not be motivated to learn if they are not interested (Ellis 2003).

They usually make mistakes in grammar. Grammar is one of English components that play an important role to avoid misunderstanding in communication. In senior high school, the students are usually confused to write correct grammar although they can speak English. They do not understand about the grammar so that they cannot analyze sentences correctly. Grammar was integrated in other four skills, in this research the researcher wants to analyze the students' errors in writing skill. Based on the curriculum, it has been mentioned that the first level students of senior high school was required to be able to understand and express meaning in short functional text and simple written monologue in forms of descriptive in their daily life context.

Based on the preliminary observation in September 2020, the researcher found that the students at Sekolah Menengah Kejuruan Swasta Bustanul Yatama Syamtalira Bayu are so hard to master writing so that they got the lower scores. Many students got the scores under 70 the criteria of success which has been determined by the school, $70 \%$ to $80 \%$ the students got the score under 70, and only $20 \%$ to $30 \%$ students got the score up to 70 , this information based on the teacher explanation. Their abilities in understanding and mastering writing were low, and in fact the teachers when teach the material to the students they do not care about these problems, they do not try to overcome these problems. The researcher tries to find out the causes from this problem, what the problems are faced by the students when they learn writing.

Based on the research problem above, the objectives in this research are:

to find out the grammatical errors are commonly made by the students of Sekolah Menengah Kejuruan Swasta Bustanul Yatama Syamtalira Bayu in their writing narrative text and to find out the causes these errors for the students of Sekolah Menengah Kejuruan Swasta Bustanul Yatama Syamtalira Bayu in their writing narrative text.

\section{Literature Review}

\section{Error Analysis}

Since interference from the learner' language is not the only source of error, analysis introduce another kind of analysis, "error analysis". Error analysis attempts to describe and explain systematically the errors made by the foreign or second language learners. (Corder 1981) explains that error analysis examines the actual errors produced by the learners in learning the target language. In short, error analysis is a devise for finding and overcoming the errors made by language learners which reflect not the structure of the first language of the learners but that of the target language.

Error analysis traditionally focuses on the invention and grouping of errors for the importance of the language teacher in the class. The objective of invention and grouping errors is to get the feedback for the organization of the teaching of the language elements. Error analysis is a process based on the analysis of learners' errors with one clear objective: evolving a suitable and effective teaching and 
learning strategy and remedial measures necessary in certain clearly marked out areas of foreign language.

In addition, (Corder 1981) explains that learners' errors are significant in three ways. First, they help the teacher to know how far his students have progressed and what he must teach to them. Second, they give the researcher evidence of how language is learned and what strategies or procedures the learners apply in order to acquire the target language. Third, the errors made by the learners are devices to prove the teacher's hypothesis about the nature of the language the students are learning. The above explanation seems to tell us that error analysis is not only important to the teacher or researcher but also to students. In order words, error analysis is essential to those involved in the process of the second language teaching and learning.

The systems of language are different from one to another. Some languages have simple systems while some other has complex systems. Linguists claim that English is one of the languages that have complex systems. It has the rules of tenses, agreement, word order, etc. Each rule has some exceptions in particular usage. The usage of articles "a" and "an" is one example. Here, learners always over generalize the usage of article "a" and "an" to the consonant sound and vowel sound, e.g. "This is a bag". "This is an eraser". Instead of "This is an bag", "This is a eraser". This expectation is undoubtedly regarded as one of the areas of the errors since foreign learners might generalize the rule. These kinds of errors are grouped into "interlingual interference" and analyzed under the error analysis.

\section{Writing}

Writing is one of important aspects in English. Writing also used to be a communication ways after speaking. An explanation about writing is necessary. (Raimes 1983) defines that writing as a system of graphic symbols that can be used to convey meaning and the act of composing a text.

Many grammarians and linguists have given the definition of writing based on the way and the background the view. Some definitions given by them will be presented below to get a clear explanation in recognizing English writing perfectly. Komba et al. (2012) states that writing is a method of representing language in visual or tactile. Writing system uses of speech and also have symbol for such thing as punctuation and numerals.

Teaching and learning writing is very important because writing is as needed as speaking in people life. Writing is used as a way to communicate each other. When people have difficulties to express their ideas as they would like to say, writing is the option to substitute the oral communication. By writing, ideas could be expressed accurately by some people, because written is easier than told directly.

(Martin 2003) says that writing is an activity made up several processes, such as thinking what to write and the order to put in. Sometimes we do not need a big preparation to write because the first things have to know what they are going to write and know what ideas will be written and our mentality to write. We write best when our purpose is communicate something to someone to communicate in written language is also necessary to concentrate on ideas expressed and grammar used correctly. Furthermore, (Pounlston 1976) says that writing is a thinking process, it 
needs the organization of thoughts and argument put into a coherent and logical way.

In other word, writing involves many language skills. They are the organization of ideas and thought into sentences, paragraph, and composition: the mental physical act of farming letters and words: the spelling of words written the punctuation and the capitalization of the words; the knowledge of matter of the form and custom in the writing required for various communication situations. (Flower 1985) says that the writing process, like any other thinking process has a way of going underground, we can struggle, ponder, writer and rewrite for two hours running, then emerge with one page of text in hand and have almost recollection of what we did all that time. According to the statement writing is one of process with which someone's brain works while doing this activity in other words, writing need mind to think, time and freedom from other activity.

Based on the definition above, the writer indeed writing is an activity or skill that has to be studied deliberately and seriously, or we can loss or even worst we do not have an capability to develop a writing systematically and scientifically, because writing need a deep knowledge to make a good written.

(Heaton 1988) also states that writing is a process which involves one's creativity in manipulating words in grammatically correct sentences and linking those sentences successfully, communicates the writer's thought and idea on a certain topic. It means that writing is a skill where the writer needs thought an idea that related to the topic, and also the writer can manipulate the word that used to make a good writing.

The aim of writing is to express or to communicate the thought, mind, hope, want and feeling of the writer in a written form, others will enjoy the writing result, besides it will be influences the thought, mind and feeling of the readers. It mean writing is one tool of communication in written form.

According to (Longman 1996), "writing is an amazing complex activity. The writer or someone who wants to write something is simultaneously involved with thinking of what to write, coherence and cohesion of text, formation and legibility of individual letters, spelling, grammar, including punctuation, layout, tone and register, organization and selection of appropriate content for an intended audience". Referring to this statement, the writer may say that writing is not an easy work to do in our communication.

Somebody who wants to communicate his ideas, feelings and thoughts with a written text, they need time to make a good planning. They have to think of what to write and how to write it. To think about a topic to write is not very difficult because in life people always face the reality and what the people want to write is always there. If they do a business in their life, of course, they will write something dealing with their business. When they are involved in social affairs, they will certainly write about social affairs and they are engaged in love, they will write about love.

Sometimes, we do not need a big preparation to write because the first things writers have to know what they are going to write and then what ideas will be written and our mentality to write. (Flower 1985) also states that writing does not begin with a pen-it begins with a mental spark. The first act of writing is noticing. 
In this case, the writer does not order the students' write grammatically. The first important point is open their way of thinking, and then they will write easily than before. They write what they are thinking and discussing with friends.

\section{Method}

This research uses a qualitative and quantitative approach and its type is a mix study. This research investigates forms, activities, characteristics, changes, relationship, similarities and differences with another phenomenon. A case study is a method used to collect and analyze data related to a case. It is a comprehensive description related to several individual aspects, groups, organizations, programs and social situations. Something can be a case because of problems, difficulties, obstacles, or deviation. The researcher gets and collects information from respondents and describes them in narrative texts. He investigates more data related to subject of the research. A case study is a method used to collect and analyze data relate to a case. It is a comprehensive description relates to several individual aspect, group, organization, program and social situation. Something can be a case because of problem, difficulty, obstacle, or deviation. The researcher gets and collects information from respondents and describes them in narrative text. The researcher investigated more data relate to subject of the research.

The sample of this research was taken from the student's writing in narrative text The sample of this reaserch selected by using random sampling technique, it is by using lottery. All of students' name was written in a sheet of paper, and the researcher take twenty of them as the sample in this study. In this study, only 20 students and one English teacher involved as the sample. To analyse the finding data will be presented in the form of percentage. The finding data will be categorized in two categories, there are: type of errors and dominant of errors. The researcher made chart to analyze the finding from the students test, the researcher categorized the type of errors made by the students in one chart, based on the scope of the research, the researcher limited this study only in basic grammar type of errors, and they are tenses: simple present tense and simple past tense, article, and sentence error. In the other chart the researcher presented the students dominant errors. In analyzing the data, the writer used a percentage system, that is by using the percentage formula.

\section{Result and Discussion}

After collecting and identifying the data, the writer tabulated and explained them in detail. First of all, the writer tried to find and then marked the errors of the sentences in the students' writing. Next, these errors were analysed and summarized in the form of tables and charts. The tables and charts were presented to answer the first and second research questions about the grammatical errors are commonly made by the students, and cause these errors made by the students. The chart showed the frequency of errors made by the students, and table showed the students errors in detail. 


\section{Grammatical Errors}

As mentioned in Chapter one, this study was only focused on the grammatical errors are commonly made by the students in writing. The grammatical errors are classified based on the scope of the research. Therefore, it was found from the students' writing that they made many grammatical errors when they were asked to write. Here is the chart of the errors is commonly made by the students:

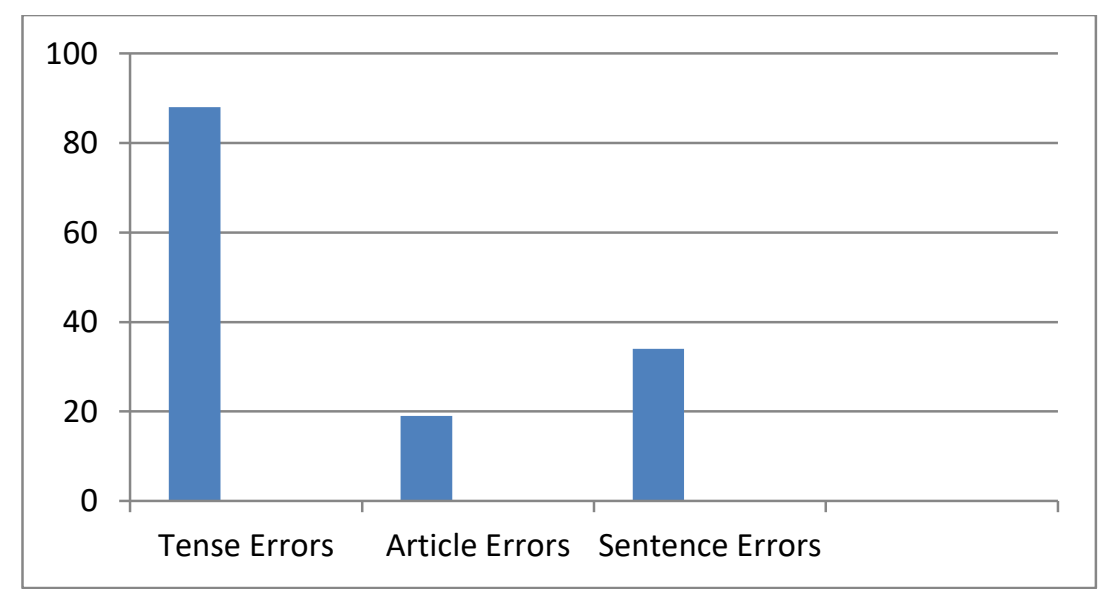

Chart 4.1. Grammatical Errors

The chart 4.1 shows the frequency of the occurrences of three grammatical errors categories found in the students' writing. They are tense errors, article errors and sentence errors. A high percentage of errors were found in one out of three categories. The highest error category was tense errors. They occurred 88 of errors, while article 19 of errors and sentence 10 of errors. Total of all errors found in these three categories are 117 errors occur in whole categories.

\section{Tense Errors}

The chart below shows the frequency of tense errors category. The highest type of errors made in this category was past tense. The errors in this category were related to the use of past verb form (main verb and auxiliary), incorrect use of infinitive, and use of pronoun. The frequency of each type in tense errors categories are shown in the following chart:



Chart 4.2. Frequency of Tense Error 
Since the students were asked to write, past tense is one of the grammatical features used in writing about experience. There are 55 cases occurring in the task based past tense:

From the students' writing, most the errors found in this tense are omission of auxiliary "was and were" and "did" in negative sentence shown in the following examples:

Table 4.1. The students' Errors in Simple Past Tense

\begin{tabular}{|c|c|c|c|}
\hline No & Students' Errors & Suggested Correction & Type of Error \\
\hline 1 & $\begin{array}{l}\text { We not permitted with } \\
\text { teacher }\end{array}$ & $\begin{array}{l}\text { We were not permitted by } \\
\text { teacher }\end{array}$ & $\begin{array}{l}\text { Omission of auxiliary } \\
\text { "were" }\end{array}$ \\
\hline 2 & $\begin{array}{l}\text { very happy at that } \\
\text { e. }\end{array}$ & $\begin{array}{l}\text { e were very happy at that } \\
\text { ne. }\end{array}$ & $\begin{array}{l}\text { Omission of auxiliary } \\
\text { "were" }\end{array}$ \\
\hline 3 & my family are very & $\begin{array}{l}\text { My family and I were very } \\
\text { happy. }\end{array}$ & $\begin{array}{l}\text { Omission of auxiliary } \\
\text { "were" }\end{array}$ \\
\hline 4 & $\begin{array}{l}\text { Last year, when I still in } \\
\text { junior high school. }\end{array}$ & $\begin{array}{l}\text { When I was still in junior } \\
\text { high school. }\end{array}$ & $\begin{array}{l}\text { Omission of auxiliary } \\
\text { "was" }\end{array}$ \\
\hline 5 & $\begin{array}{l}\text { We was visited the air } \\
\text { tawar lake. }\end{array}$ & We visited Air Tawar lake. & $\begin{array}{l}\text { Addition of auxiliary } \\
\text { "was" }\end{array}$ \\
\hline 6 & We a & We & $\begin{array}{l}\text { Addition (double), } \\
\text { and misinformation of } \\
\text { auxiliary "were" }\end{array}$ \\
\hline 7 & $\begin{array}{l}\text { We not ignored the } \\
\text { attention. }\end{array}$ & $\begin{array}{l}\text { We did not ignore the } \\
\text { attention. }\end{array}$ & $\begin{array}{l}\text { Omission of auxiliary } \\
\text { "did" }\end{array}$ \\
\hline
\end{tabular}

The table 4.1 shown the frequency of omission of auxiliary "was, were and did" was dominant, the students also made error in addition and misinformation of auxiliary "were". Another problem involves the misinformation of verb, in which the students put double mark in their sentences and sometime omit the past form of the verb to show the action in the past:

Table 4.2. The Students' Errors in Simple Past Tense

\begin{tabular}{|c|c|c|c|}
\hline No & Students' Errors & Suggested Correction & Type of Error \\
\hline 1 & $\begin{array}{l}\text { When I arrive in } \\
\text { Banda Aceh }\end{array}$ & $\begin{array}{l}\text { When I arrived in } \\
\text { Banda Aceh }\end{array}$ & $\begin{array}{l}\text { Misinformation of the verb } \\
\text { "arrive" }\end{array}$ \\
\hline 2 & $\begin{array}{l}\text { We were arrived } \\
\text { there. }\end{array}$ & We arrived there. & $\begin{array}{l}\text { Addition of auxiliary } \\
\text { "were" in affirmative } \\
\text { sentence. }\end{array}$ \\
\hline 3 & $\begin{array}{l}\text { We was enjoy the } \\
\text { view. }\end{array}$ & We enjoyed the view. & $\begin{array}{l}\text { Addition of auxiliary "was" } \\
\text { and misinformation of the } \\
\text { verb "enjoy" }\end{array}$ \\
\hline 4 & $\begin{array}{l}\text { Yesterday, I go to the } \\
\text { beach. }\end{array}$ & $\begin{array}{l}\text { Yesterday, I went to the } \\
\text { beach. }\end{array}$ & $\begin{array}{l}\text { Misinformation of the verb } \\
\text { "go" }\end{array}$ \\
\hline 5 & We study together & We studied together & $\begin{array}{l}\text { Misinformation of the verb } \\
\text { "study" }\end{array}$ \\
\hline 6 & $\begin{array}{l}\text { I ask the money from } \\
\text { my father }\end{array}$ & $\begin{array}{l}\text { I asked the money from } \\
\text { my father }\end{array}$ & $\begin{array}{l}\text { Misinformation of the verb } \\
\text { "ask" }\end{array}$ \\
\hline 7 & $\begin{array}{l}\text { They take the } \\
\text { motorcycle }\end{array}$ & $\begin{array}{l}\text { They took the } \\
\text { motorcycle }\end{array}$ & $\begin{array}{l}\text { Misinformation of the verb } \\
\text { "take" }\end{array}$ \\
\hline
\end{tabular}


The table 4.2 shown that the students' errors were dominant in misinformation of the verb, they used infinitive verb in the past tense sentence, and also the students added of auxiliary "were" in affirmative sentence.

There are 33 cases occurring in the students' writing in the category of simple present tense, such as when the students put the past form instead of simple form, and when the verb is added with third singular inflection (-s). For example:

Table 4.3. The Students' Errors in Simple Present Tense

\begin{tabular}{|c|c|c|c|}
\hline No & Students' Errors & Suggested Correction & Type of Error \\
\hline 1 & I helps mother everyday & I help mother every day & $\begin{array}{l}\text { Misinformation of the } \\
\text { verb "help" }\end{array}$ \\
\hline 2 & $\mathrm{p}$ at 06.00 & I wake up at $06.00 \mathrm{e}$ & $\begin{array}{l}\text { Misinformation of the } \\
\text { verb "wake" }\end{array}$ \\
\hline 3 & .. & ...the sun rises... & nation of the \\
\hline 4 & ects the task & $\mathrm{y}$ & $\begin{array}{l}\text { nation of the } \\
\text { ect" }\end{array}$ \\
\hline 5 & $\mathrm{y}, \mathrm{I}$ and my & , my father & rmation of the \\
\hline 6 & $\begin{array}{l}\text { Teacher teach us the } \\
\text { lesson }\end{array}$ & $\begin{array}{l}\text { Teacher teaches us the } \\
\text { lesson }\end{array}$ & $\begin{array}{l}\text { Misinformation of the } \\
\text { verb "teach" }\end{array}$ \\
\hline 7 & My father drive the car & My father drives the & $\begin{array}{l}\text { Misinformation of the } \\
\text { verb "drive" }\end{array}$ \\
\hline
\end{tabular}

The table 4.3 shown that the students" errors were dominant in missing "s" after verb, and sometime they added "s" after verb. These errors occurred because of the students did not understand about simple present tense.

\section{Article Errors}

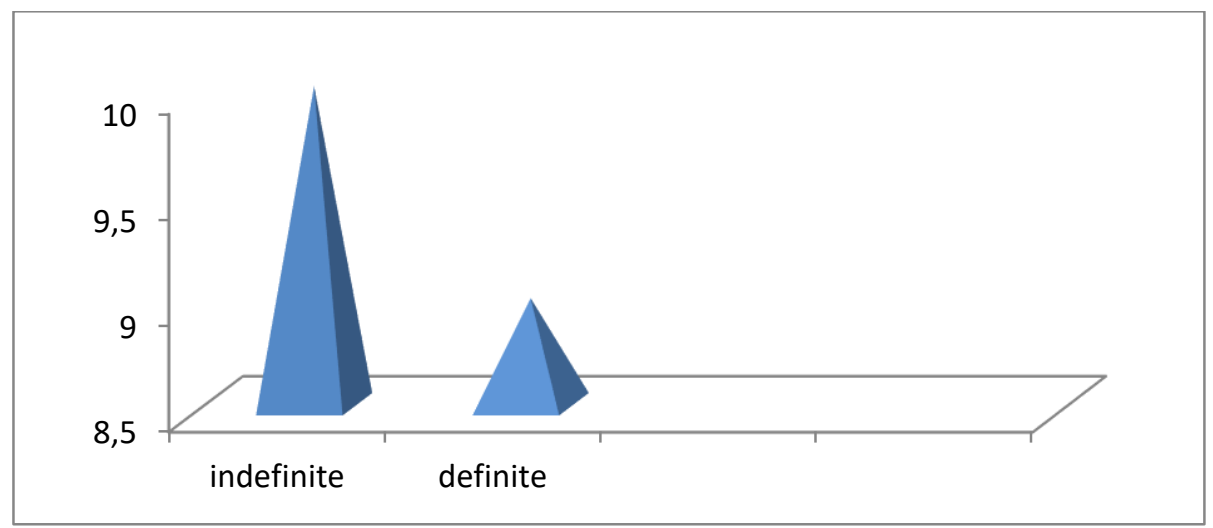

Chart 4.3. Frequency of Article Errors

The errors on the use of article both definite and indefinite articles were also found in the students' writing. There were 9 errors dealing with definite article and 10 errors with indefinite article. Here are the following some errors found in the students' sentences: 
Table 4.4. The Students' Errors in Article

\begin{tabular}{|c|c|c|c|}
\hline No & Students' Errors & Suggested Correction & Type of Error \\
\hline 1 & $\begin{array}{l}\text { I bought pen in the } \\
\text { market }\end{array}$ & I bought a pen in the market & $\begin{array}{l}\text { Omission of } \\
\text { indefinite article "a" }\end{array}$ \\
\hline 2 & ...and coming in market. & ... and coming in a market. & $\begin{array}{l}\text { Omission of } \\
\text { indefinite article "a" }\end{array}$ \\
\hline 3 & I buy new hand phone... & I buy a new hand phone... & $\begin{array}{l}\text { Omission of } \\
\text { indefinite article "a" }\end{array}$ \\
\hline 4 & $\begin{array}{l}\text { We go to the Suzuya in } \\
\text { the Monday. }\end{array}$ & We go to Suzuya in Monday & $\begin{array}{l}\text { Addition of } \\
\text { unnecessary article } \\
\text { "the" }\end{array}$ \\
\hline 5 & $\begin{array}{l}\text { I stay in the my family } \\
\text { house }\end{array}$ & I stay in my family house & $\begin{array}{l}\text { Addition of } \\
\text { unnecessary article } \\
\text { "the" }\end{array}$ \\
\hline 6 & We are went to beach & We went to the beach & $\begin{array}{l}\text { Omission of definite } \\
\text { article "the" }\end{array}$ \\
\hline 7 & $\begin{array}{l}\text { The school near from } \\
\text { house }\end{array}$ & $\begin{array}{l}\text { The school is near from the } \\
\text { house }\end{array}$ & $\begin{array}{l}\text { Omission of definite } \\
\text { article "the" }\end{array}$ \\
\hline 8 & I go to school... & I go to the school... & $\begin{array}{l}\text { Omission of definite } \\
\text { article "the" }\end{array}$ \\
\hline 9 & We prepare for holiday & We prepare for the holiday & $\begin{array}{l}\text { Omission of definite } \\
\text { article "the" }\end{array}$ \\
\hline 10 & $\begin{array}{l}\text { We go to swimming pool } \\
\text { together }\end{array}$ & $\begin{array}{l}\text { We go to the swimming } \\
\text { pool together }\end{array}$ & $\begin{array}{l}\text { Omission of definite } \\
\text { article "the" }\end{array}$ \\
\hline
\end{tabular}

\section{Sentence Errors}

The table 4.4 shown that the students made errors in omitting definite article, sometime the students omitted definite article "the" and sometime article "a", then, the students also made errors by adding unnecessary article in the sentence.

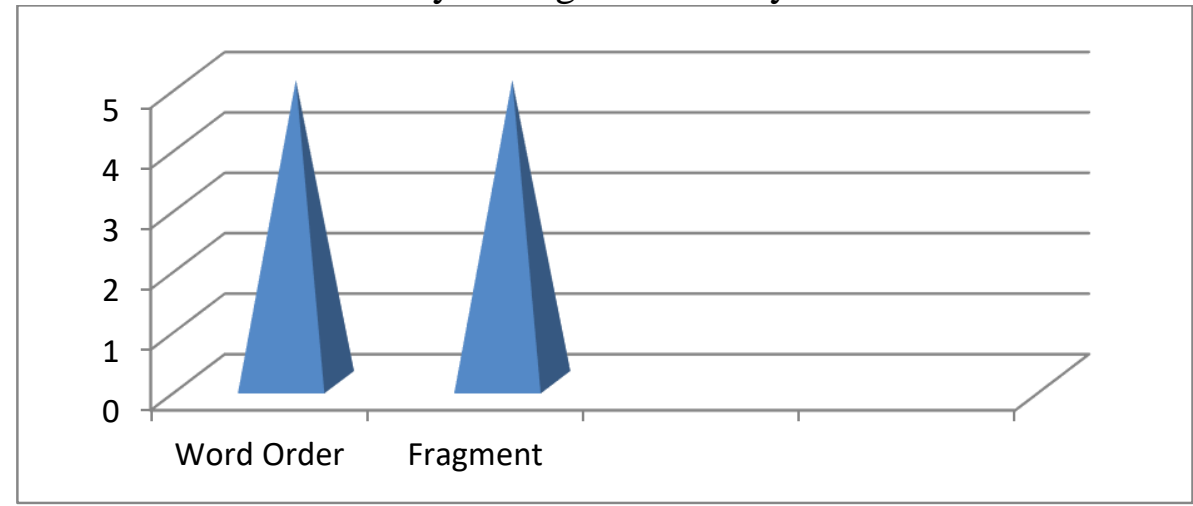

\section{Chart 4.4. Frequency of Sentence Errors}

The chart above presents the frequency of sentence errors category. The errors made in this category were related to the errors of word order, and incomplete sentences.

There were 5 errors related to the incorrect use of word order. There is a problem of the position of adjective as modifier noun. Here are some errors from the students' writing: 
Table 4.5. The Students' Errors in Word Order

\begin{tabular}{|c|c|c|c|}
\hline No & Students' Errors & Suggested Correction & Type of Error \\
\hline 1 & Chicken fried & Fried chicken & $\begin{array}{l}\text { Disordering of the } \\
\text { word "fried" as } \\
\text { modifier }\end{array}$ \\
\hline 2 & $\begin{array}{l}\text { We needed getting score } \\
\text { high }\end{array}$ & We needed to get high score & $\begin{array}{l}\text { Disordering of the } \\
\text { word "high" as } \\
\text { modifier }\end{array}$ \\
\hline 3 & $\begin{array}{l}\text { They waited instruction } \\
\text { teacher }\end{array}$ & $\begin{array}{l}\text { They waited teacher } \\
\text { instruction }\end{array}$ & $\begin{array}{l}\text { Disordering of the } \\
\text { word "teacher" as } \\
\text { modifier }\end{array}$ \\
\hline 4 & View good & Good view & $\begin{array}{l}\text { Disordering of the } \\
\text { word "good" as } \\
\text { modifier }\end{array}$ \\
\hline 5 & ...to Island Samosir & ...to Samosir Island & $\begin{array}{l}\text { Disordering of the } \\
\text { word "Samosir" as } \\
\text { modifier }\end{array}$ \\
\hline
\end{tabular}

The table 4.5 shown that all of the students' errors in disordering of the word noun as modifier. These errors were common error with the students because fist language (F1) interference.

This error was found from the students' writing. It is characterized by the omission of the subject of the sentence. Here are some errors the students made:

Table 4.6. The Students' Errors in Fragment

\begin{tabular}{|c|c|c|c|}
\hline No & Students' Errors & Suggested Correction & Type of Error \\
\hline 1 & $\begin{array}{l}\text { Yesterday, went to other } \\
\text { place }\end{array}$ & $\begin{array}{l}\text { Yesterday, we went to other } \\
\text { places }\end{array}$ & $\begin{array}{l}\text { Omission of subject } \\
\text { pronoun "we" }\end{array}$ \\
\hline 2 & $\begin{array}{l}\text { In the morning, must } \\
\text { clean the class }\end{array}$ & $\begin{array}{l}\text { In the morning, we must } \\
\text { clean the class }\end{array}$ & $\begin{array}{l}\text { Omission of subject } \\
\text { pronoun "we" }\end{array}$ \\
\hline 3 & $\begin{array}{l}\text { After lunch, must come } \\
\text { to extracurricular class }\end{array}$ & $\begin{array}{l}\text { After lunch, we must come } \\
\text { to extracurricular class }\end{array}$ & $\begin{array}{l}\text { Omission of subject } \\
\text { pronoun "we" }\end{array}$ \\
\hline 4 & $\begin{array}{l}\text { Last year, when in junior } \\
\text { high school }\end{array}$ & $\begin{array}{l}\text { Last year, when I was in } \\
\text { junior high school }\end{array}$ & $\begin{array}{l}\text { Omission of subject } \\
\text { pronoun "I" }\end{array}$ \\
\hline 5 & $\begin{array}{l}\text { In Brastagi, slept in the } \\
\text { hotel }\end{array}$ & In Brastagi, I slept in a hotel & $\begin{array}{l}\text { Omission of subject } \\
\text { pronoun "I" }\end{array}$ \\
\hline
\end{tabular}

From all data of kind of grammatical errors, it was concluded that tense errors, article errors, and sentence errors are found in students' writing. This is the answer of first research question on the grammatical errors made by the students of Sekolah Menengah Kejuruan Swasta Bustanul Yatama Syamtalira Bayu in writing.

The finding of the research result of identifying and classifying the error category and types of error is discussed below. The errors made by the students were tabulated in percentage in order to find out the most difficult ones for student. They are shown in table below: 
Table 4.7. The Percentage of Errors Types Occurrences

\begin{tabular}{clc}
\hline No & \multicolumn{1}{c}{ Type of Errors } & Percentage (\%) \\
\hline 1 & Past Tense & 47 \\
2 & Present Tense & 28.2 \\
3 & Definite Article & 7.7 \\
4 & Indefinite Article & 8.5 \\
5 & Word Order & 4.3 \\
6 & Fragment & 4.3 \\
\hline
\end{tabular}

The frequency of the occurrences of three grammatical errors categories found in the students' writing. They are tense errors, article errors and sentence errors. A high percentage of errors were found in one out of three categories. The highest error category was tense errors. They occurred 88 of errors, while article 19 of errors and sentence 10 of errors. Total of all errors found in these three categories are 117 errors occur in whole categories.

The researcher had the data of the students' error with the data of interviewing some students and teacher. These data are used to answer the second research question. The researcher had interviewing the teacher before the students completed the task. The researcher asked him how to teach writing to students, including the curriculum standard and students' motivation.

The researcher asked five questions for teacher to get the data to answer the second research question in this study. The first question is "what errors are often made by the students in writing?". Based on the teacher's answer the researcher concluded that the students frequent made errors in tenses and word order. For the example: "I eat ice cream yesterday" but the right one he should write "I ate ice cream yesterday".

The second question is "what are causes these errors made by students in writing?". The teacher said that the errors were made by the students because of lack of sense of vocabulary use so they cannot develop their writing as effectively as possible. Beside that, lack of interactive facilities is one of the problems to develop interactive classroom activities, and also because they dislike studying grammar. So, that causes made the students could not composed in a good writing. These problems also made the students difficult to express their ideas in writing.

The third question is "what are the difficulties faced in teaching writing?". According to the teacher, lack of interactive facilities is one of the problems to develop interactive classroom activities. In addition, decision maker should have a real action to support toward the improvement of English acquisition, especially in writing mastery, and when he taught writing for the students he found some problems because the students have no ideas for writing, they beefed about writing because they dislike writing, they felt writing is very difficult because they should wrote in good grammar. Then, the teacher also got problem when some students did not want to write something.

The fourth question is" what are the difficulties faced by students in learning writing?". According to teacher, the students got difficulties in expressing their idea in writing, because they lack of vocabulary. This was serious problem for the 
students, the teacher should increased the students vocabulary mastery to make the students able to write better.

The last question for teacher is "how did you solve these problems in learning writing?". The researcher concluded from the teacher's answer that he solved the problem by using some ways. First, the teacher taught writing by using fun method for the students, such as using picture and teacher was communicative enough in teaching. Then, the teacher did not determine the topic of writing but the students could write freely. This way made the students relax and enjoy in learning writing.

The researcher also asked five questions for some students to get the data to answer the second research question in this study. The first question is "are you happy to study grammar when learning writing?". Based on the students answer the researcher concluded that they felt happy to study writing, but they felt confused and bored with grammar. They felt happy without considering about grammar when they expressed their ideas in writing.

The second question is "what are difficulties materials in learning grammar?". Students said that they confused with tenses, because they difficult to differentiate among present and past, they also said because too much tenses that they should learnt. Then, the students felt difficult to remember the terms of grammar in English because very much terms in English.

The third question is "what are causes of errors made by you in learning writing?". The students said that causes of errors because they did not care about grammar when they expressed their idea in writing, if they though about grammar they would loosed their idea to write. Then, when the students started to write they often did not bring the dictionary to the school, so, this problem made the students difficult to write their idea because lack of vocabulary.

The fourth question is "what grammatical errors are commonly made by you in writing?". The grammatical errors are commonly made by students such as verb tense, word order and confusing word choice, and spelling, and they are careless about article, preposition, pronoun, comma splices, and etc.

The last question for students is "how did you solve these errors in learning writing?". The students have some ways to solve these errors, firstly, the students should learnt about grammar seriously before starting to learn writing skill, secondly, they should brought dictionary everyday when learning English, this way was very important, because lack of vocabulary they could not write completely their ideas without dictionary. The last, they should learnt English especially writing skill harder than before.

\section{Conclusion}

There were two problems which appeared in the research question. What grammatical errors are commonly made by the students of Sekolah Menengah Kejuruan Swasta Bustanul Yatama Syamtalira Bayu in their writing narrative text? And What causes these errors difficult for the students of Sekolah Menengah Kejuruan Swasta Bustanul Yatama Syamtalira Bayu in their writing narrative text? The frequency of the occurrences of three grammatical errors categories found in the students' writing narrative text. They are tense errors, article errors and sentence errors. A high percentage of errors were found in one out of three categories. The 
highest error category was tense errors. They occurred 88 of errors, while article 19 of errors and sentence 10 of errors. Total of all errors found in these three categories are 117 errors occur in whole categories. Almost all students made errors in using past tense, especially in the changing of the verb to past form for activities done in the past. The students tend to use the simple verb form instead of past tense verb while they write about their writing. This is called as misinformation errors. The students actually wrote correctly for what they wanted to tell but they made these errors grammatically in meaning. In this case, (Norrish 1983) says that these errors might occur because of interference by students' first language and translation from the first language. Moreover, the errors are also characterized by the omission both affirmative and negative sentences.

\section{Acknowledgement}

First and foremost, all praises and thanks are due to Allah Subhana Wata'ala who has given the researcher health, strength and capability in writing this article. Besides, peace and blessings be upon to our prophet Muhammad (peace be upon him), and his companions who guided mankind from ignorance to straight path of Islam. who has given the researcher health, knowledge, and opportunity to write and finish this article entitled "An Error Analysis of Students' Writing in Narrative Text to the Students Sekolah Menengah Kejuruan Swasta Bustanul Yatama Syamtalira Bayu". Peace and blessing be on prophet Muhammad Salallahu'alaihi wasalam, who had brought us from the darkness to the lightness. He would like to express his deepest and greatest gratitude to his Co-Author Mrs. Nurul Kamaliah, S.Pd.I., M.Pd who gave him many valuable ideas, critics, suggestion and guidance in writing this article. Next, his sincere thanks are dedicated to the headmaster and the English teacher of sekolah menengah kejuruan swasta Bustanul Yatama who had given the researcher chance to take the research in the school. His deeper thanks are also due to all lectures in STKIP Bumi Persada Lhokseumawe. Finally, the researcher sincerely hopes the readers to give theirs critics and responses to rectify and correct any defects and errors of this article, so that it becomes perfect. May this article be useful in the future to increase our knowledge, may Allah Subhana Wata'ala bless us forever, Aamiin Ya Rabbal 'Alamin.

\section{REFERENCES}

Corder, S. P. 1981. Error Analysis and Interlanguage. Oxford: Oxford University Press.

Ellis, R. 2003. Understanding Second Language Acquisition. Oxford: Oxford University Press.

Flower, L. 1985. Problem Solving Strategies for Writing. London: Publisher Mellon University.

Heaton, JB. 1988. Writing English Language Test, Revised Edition. London: Longman.

Komba, S. C., E. J. Kafanabo, A. F. Njabili, and E. S. Kira. 2012. "Comparison between Students' Academic Performance and Their Abilities in Written 
English Language Skills: A Tanzanian Perspective.” International Society for Development and Sustainability 1(2):305-25.

Longman. 1996. Writing Resource Book. Sydney: National Library.

Martin, H. M. 2003. Oxford Learner's Pocket Dictionary. New York: Oxford University Press.

Norrish, J. 1983. Language Learners and Their Errors. London: Macmillan.

Nunan., David. 1995. Language Teaching Methodology: A Text Book for Teacher. Trenton: Prentice Hall.

Pounlston, B. 1976. Teaching English as Second Language and Procedure. New York: Little Brown and Company.

Raimes, A. 1983. Technique in Teaching Writing. Oxford: Oxford University Press. 